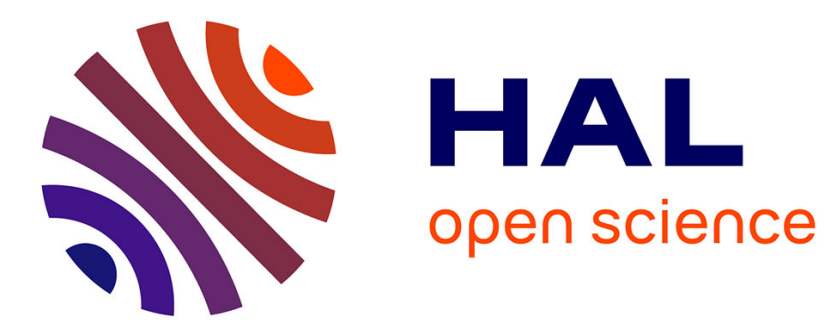

\title{
The timing of moult in males and females of the monomorphic Pale-winged Starling Onychognathus nabouroup
}

Adrian J. F. K. Craig, Martine Hausberger, Bo Bonnevie, Laurence Henry

\section{- To cite this version:}

Adrian J. F. K. Craig, Martine Hausberger, Bo Bonnevie, Laurence Henry. The timing of moult in males and females of the monomorphic Pale-winged Starling Onychognathus nabouroup. African Zoology, 2015, 50 (1), pp.69-71. 10.1080/15627020.2015.1021548 . hal-01150388

HAL Id: hal-01150388

https://hal-univ-rennes1.archives-ouvertes.fr/hal-01150388

Submitted on 15 Sep 2015

HAL is a multi-disciplinary open access archive for the deposit and dissemination of scientific research documents, whether they are published or not. The documents may come from teaching and research institutions in France or abroad, or from public or private research centers.
L'archive ouverte pluridisciplinaire HAL, est destinée au dépôt et à la diffusion de documents scientifiques de niveau recherche, publiés ou non, émanant des établissements d'enseignement et de recherche français ou étrangers, des laboratoires publics ou privés. 


\title{
The timing of moult in males and females of the monomorphic Pale-winged Starling Onychognathus nabouroup
}

\author{
Adrian JFK Craig ${ }^{1,4}$, Martine Hausberger², Bo Bonnevie ${ }^{3}$ and Laurence Henry ${ }^{2}$ \\ 1 Department of Zoology and Entomology, Rhodes University, Grahamstown, South Africa \\ 2 UMR CNRS 6552 Ethologie animale et humaine, Université de Rennes-1, Rennes, France \\ 3 Information Technology Division, Rhodes University, Grahamstown, South Africa \\ *Corresponding author, email: a.craig@ru.ac.za
}

\begin{abstract}
Pale-winged Starlings Onychognathus nabouroup inhabit the arid western interior of southern Africa and moultbreeding overlap may occur. We collected field data in two successive years on the moult of individual birds, whose sex was confirmed by genetic techniques. Small samples revealed a non-significant tendency for the moult of females in the early stages of wing moult to be more advanced than that of males in both years, but also clear evidence that the starting date of moult differed in the two years. In this species the moult schedule may thus be variable at both the individual and the population levels.
\end{abstract}

Keywords: moult, Onychognathus, sexual dimorphism, southern Africa, starling

As one of the major events in the annual cycle of all birds, the timing of the complete moult should be adjusted to the requirements of the individual bird, as well as being subject to selection at the species level (Stresemann and Stresemann 1966; Barta et al. 2006). Recent studies of South African passerine birds have shown that the timing of moult often varies regionally relative to the timing of rainfall in relation to the breeding season (Hulley et al. 2004; Craig et al. 2010). In addition, in some sexually dimorphic species the post-breeding moult starts earlier in males than in females (Bonnevie and Oschadleus 2010). This could be ascribed to reduced male involvement in the care of the young in such species (Verner and Willson 1969; Payne 1984; Oschadleus and Osborne 2005).

Of the 11 members of the genus Onychognathus, only two species are not sexually dimorphic in plumage. Male and female Pale-winged Starlings $O$. nabouroup are not distinguishable on plumage characters (Craig and Feare 2009), although they can be separated in the hand with some confidence by a combination of morphological measurements ( $\mathrm{LH}$ et al. unpublished data). Earlier work has shown that moult and breeding in this arid-zone species can overlap at both the individual and the population level (Craig 2012). This raises the question as to whether males and females differ in the timing of their moult, which could reflect different investments in parental care. Therefore we investigated the stage of primary moult of wild Pale-winged Starlings, which were later sexed by genetic methods.

The study was carried out in Augrabies Falls National Park, Northern Cape, South Africa, (28 $\left.{ }^{\circ} 59^{\prime} \mathrm{S}, 2^{\circ} 33^{\prime} \mathrm{E}\right)$ over two consecutive years. From 25 to 28 October 2011, a sample of 58 adult birds was captured and 42 of these individuals were subsequently sexed. From 1 to 7 November 2012 an additional 24 adult birds were captured, all of which were sexed, and two birds ringed and sexed in the previous year were recaptured. Birds were caught in baited clap traps, individually colour-ringed for behavioural observations, and released at the capture site. None had brood patches, and it appeared that nesting had not yet started in either year. Standard measurements (wing, tail, tarsus and culmen length in millimetres, body mass in grams) were taken, and primary wing-moult was scored according to the system whereby 0 = an old feather, $5=$ a fully grown new feather, with 1-4 representing intermediate growth stages (Ginn and Melville 1983). These scores were converted to 'percentage feather mass grown' for analysis in the moult model of Underhill and Zucchini (1988) as written for R (Erni et al. 2013). Sex was ascertained by DNA sexing (Labofarm, France) from samples of 5-10 small feathers from each bird (Han et al. 2009).

One female bird had interrupted wing moult, with the two inner primaries new, the rest old, and no growing feathers, although there were some body feathers moulting. This is the first record of interrupted primary moult in this species (Craig 2012), and there is no apparent explanation for its occurrence in this bird. Although the sample sizes were relatively small, in both years the stage of moult as represented by the outermost growing primary remix showed a normal distribution, with wing moult in female birds rather more advanced than in males (Figure 1). The data were then examined statistically (using the Welch two-sample $t$-test), comparing mean percentage new feather mass grown in males and females in each year. In 2011 females were on average more advanced in their 


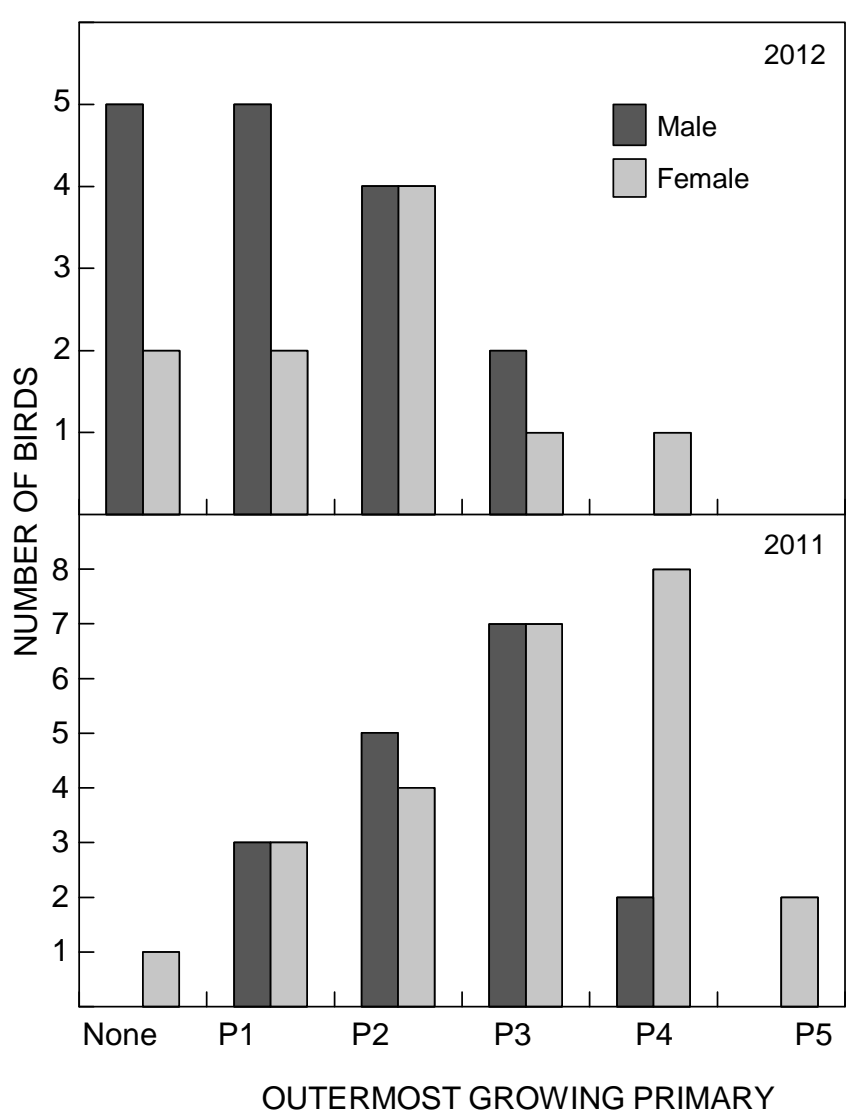

Figure 1: Stage of early primary moult of male and female Palewinged Starlings handled at Augrabies Falls National Park, South Africa, from 25 to 28 October 2011 and 1 to 7 November 2012. Moult starts at P1 and proceeds outwards to P9; the $x$-axis shows the outermost growing primary in each case

moult, and the difference approached significance at the $5 \%$ level $(N=17$ males, 25 females, $P=0.064)$. For 2011 there was also an indication that female moult was more advanced, but this was far from being statistically significant ( $N=16$ males, 10 females, $P=0.503)$.

However, for both males and females there was a significant difference between the years. In 2011 data were collected mostly during the last week of October, whereas in 2012 all birds were captured after 1 November. Yet moult was significantly more advanced in 2011 than in 2012 (Welch two-sample $t$-test, comparing mean percentage feather mass grown; for males, $P=0.018$; for females $P=0.009$ )

Among the museum specimens examined previously (Craig 2012), there are 21 instances in which a male and a female Pale-winged Starling were collected on the same date at the same locality. Of these 'pairs', eight had wing moult: in four cases moult had reached the same primary in both birds (January [2], March [1], November [1]); one male had more advanced primary moult than the corresponding female (January), whereas three females had more advanced wing moult than their male counterparts (January [2], February [1]). This also hints at a tendency for moult in females to be more advanced than in male birds.
The Red-winged Starling Onychognathus morio, a sexually dimorphic species, favours more humid habitats, but is locally sympatric with the Pale-winged Starling in South Africa (Craig and Feare 2009). Moult-breeding overlap also occurs in this species, but there is no significant difference in the timing or duration of wing moult in male and female Red-winged Starlings in the winter rainfall region of the Western Cape (Bonnevie and Oschadleus 2010). On the arid island of Socotra, two Onychognathus species occur, the Somali Starling $O$. blythii and the Socotra Starling $O$. frater. During the same three-week period, Gedeon and Neumann (2004) handled three female Somali Starlings in very different stages of wing moult, whereas three males were not moulting. This may also imply less synchronous moult in harsh environments.

Although some field studies suggest survival costs to passerine birds that overlap moulting and breeding (Echeverry-Galvis and Hau 2013), others have found improved survival in such individuals (Morales et al. 2007; Buchmann et al. 2009). In understorey passerines in central Amazonia, Johnson et al. (2012) found that species with slower feather growth rates and a longer moult duration were more likely to overlap moulting and breeding. Few studies have directly measured the metabolic costs of moult, but in the White-plumed Honeyeater Lichenostomus penicillatus Hoye and Buttemer (2011) found that extending the moult period significantly reduced the energetic costs of feather replacement on a daily basis in this opportunistically breeding arid-zone bird.

For Pale-winged Starlings it appears that moult-breeding overlap is a regular phenomenon (Craig 2012), whereas the timing of breeding can vary markedly, probably dependent on local rainfall. As in other starlings of this African radiation only females incubate, but both sexes feed chicks in the nest (Craig and Feare 2009). However, the period of juvenile dependence on the adults has not been accurately determined; to date only females (colour-ringed birds, sexed from genetic samples) have been seen feeding fledglings out of the nest (February; $\mathrm{MH}$ pers. obs.). Our current data suggest that primary wing moult may start earlier and/or progress more rapidly in females than in males in this species. We cannot yet offer any biological explanation for this, but differences between the sexes in parental care, and in the subsequent timing of the annual moult, are known in both sexually dimorphic and monomorphic species (cf. Svensson and Nilsson 1997; Hemborg 1999). We also need more information from the entire moulting period, as it is possible that changes in the rate of feather replacement may occur at different stages of the moult cycle. The fact that differences in the timing of moult were observed in successive seasons confirms the flexibility of the breeding and moulting strategies in this arid-zone species.

Acknowledgements - We are indebted to South African National Parks for permission to capture and ring birds at Augrabies Falls National Park, and we are grateful to the park staff for their cooperation. The sexing of the birds depended on the laboratory skills of the staff at Labofarm in Loudeac, France. We also thank Mike Ford, Arjen van Zwieten, Diane Smith, Pat Hulley and Mary Hulley for their assistance in catching and ringing the birds. This project has been funded by the CNRS (France) and the National Research 
Foundation (South Africa) through the PICS programme for international collaborative research. Additional funding has been provided by Rhodes University.

\section{References}

Barta Z, Houston AT, McNamara JM, Welham RK, Hedenström A, Weber TP, Fero O. 2006. Annual routines of non-migratory birds: optimal moult strategies. Oikos 112: 580-593.

Bonnevie BT, Oschadleus HD. 2010. Timing of primary wing moult in sexually dimorphic passerines from the Western Cape, South Africa. Ostrich 81: 63-67.

Buchmann M, Helm B, Rothery P, Flinks H. 2009. Auswirkung von Spätbruten auf Mauser und Rückkehrrate bei einem Weitstreckenzieher dem Steinschmätzer (Oenanthe oenanthe). Vogelwarte 47: 125-133.

Craig AJFK. 2012. Regular moult-breeding overlap in the Palewinged Starling Onychognathus nabouroup. Ostrich 83: 169-170.

Craig AJFK, Bonnevie BT, Oschadleus HD. 2010. Regional patterns in moult and sexual dimorphism of adult Southern Red Bishops Euplectes orix in southern Africa. Ostrich 81: 123-128.

Craig AJFK, Feare CJ. 2009. Family Sturnidae (starlings). In: del Hoyo J, Elliott A, Christie D (eds), Handbook of the birds of the world, vol. 14: Bush-shrikes to Old World Sparrows. Barcelona: Lynx Edicions. pp 654-758.

Echeverry-Galvis MA, Hau M. 2013. Flight performance and feather quality: paying the price of overlapping moult and breeding in a tropical highland bird. PLoS One 8: e61106.

Erni B, Bonnevie BT, Oschadleus HD, Altwegg R, Underhill LG. 2013. moult: An $R$ package to analyse moult in birds. Journal of Statistical Software 52(8): 1-23.

Gedeon K, Neumann V. 2004. Notes on Socotra Starling Onychognathus frater and Somali Starling O. blythii Hartlaub 1859 (Aves) on Socotra Island. Fauna of Arabia 20: 535-548.

Ginn HB, Melville DS. 1983. Moult in birds. Tring: British Trust for Ornithology.
Han J-I, Kim J-H, Kim S, Park S-R, Na K-J. 2009. A simple and improved DNA test for avian sex determination. The Auk 126: 779-783.

Hemborg C. 1999. Annual variation in the timing of breeding and moulting in male and female Pied Flycatchers Ficedula hypoleuca. Ibis 141: 226-232.

Hoye BJ, Buttemer WA. 2011. Inexplicable inefficiency of avian moult? Insights from an opportunistically breeding arid-zone species Lichenostomus penicillatus. PLOS ONE 6: e16230.

Hulley PE, Craig AJFK, Underhill GD, Bonnevie BT, Nuttall RJ, de Swardt DH. 2004. Timing of moult and breeding in the Cape White-eye Zosterops pallidus from three different geographical regions in South Africa. Emu 104: 353-358.

Johnson El, Stouffer PC, Bierregaard RO. 2012. The phenology of moulting, breeding, and their overlap in central Amazonian birds. Journal of Avian Biology 43: 141-154.

Morales J, Moreno J, Merino S, Sanz JJ, Tomás G, Arriero E, Lobato E, Martínez-de la Puente, J. 2007. Early moult improves local survival and reduces reproductive output in female pied flycatchers. Ecoscience 14: 31-39.

Oschadleus HD, Osborne T. 2005. Chestnut Weaver Ploceus rubiginosus biometrics and primary moult in Namibia. Ostrich 76: 206-211.

Payne RB. 1984. Sexual selection, lek and arena behavior, and sexual size dimorphism in birds. Ornithological Monographs 33: $1-52$.

Stresemann E, Stresemann V. 1966. Die Mauser der Vögel. Journal für Ornithologie 107 (Sonderheft): 1-445.

Svensson E, Nilsson J-A. 1997. The trade-off between moult and parental care: a sexual conflict in the Blue Tit? Behavioral Ecology 8: 92-98.

Underhill LG, Zucchini W. 1988. A model for avian primary moult. Ibis 130: 358-372.

Verner J, Willson MF. 1969. Mating systems, sexual dimorphism, and the role of male North American passerine birds in the nesting cycle. Ornithological Monographs 9: 1-76. 